\title{
Two sympatric phylogroups of the Asian badger Meles leucurus (Carnivora: Mammalia) identified by mitochondrial DNA cytochrome $b$ gene sequences
}

\author{
Hung Sun Koh*, Alexey Kryukov, Jang Geun Oh, Damdingiin Bayarkhagva, \\ Byeng Gug Yang, Na Hyun Ahn \& Dava Bazarsad
}

ABSTRACT. We obtained 20 complete cytochrome $b$ sequences (1140 bp) of Meles leucurus from the Korean Peninsula (mainland Korea and Jeju Island), Russian Far East, and Mongolia, and these sequences were compared to complete and partial (629 bp) sequences of M. leucurus, obtained from GenBank, in order to reexamine genetic differentiation among M. leucurus from Korea, Siberian and Far-eastern Russia, Mongolia, and China. We detected that M. leucurus is composed of two sympatric phylogroups (a major phylogroup from the Urals, Siberia, Mongolia, China, and mainland Korea and a minor phylogroup from China, Far-eastern Russia, mainland Korea, and Jeju Island), indicating that M. leucurus is a monotypic species in the cytochrome $b$ gene. Thus, we concluded that our sequencing results do not support current subspecies classification of $M$. leucurus, recognizing it as a polytypic species, although further genetic analyses with other markers are needed to confirm our present findings. We also considered that $M$. leucurus from China and Russian Far East is in contact with M. leucurus from mainland Korea and Jeju Island during the last glacial period, although in both Jeju and Russian Far East the specimens belonging to one of the two phylogroups are found at present. Additionally, we considered that the degree of genetic divergence between insular M. anakuma from Japan and continental M. leucurus from mainland Asia is not so great that our sequencing results do not support current species classification, recognizing $M$. leucurus as a distinct species: we proposed further systematic analyses to clarify the specific status of M. anakuma.

KEY WORDS: DNA systematics, phylogeography, cytochrome $b$, Meles leucurus, Asia.

Hung Sun Koh [syskoss@chungbuk.ac.kr], Department of Biology, Chungbuk National University, Cheongju 361763, Korea; Alexey Kryukov [kryukov@ibss.dvo.ru], Laboratory of Evolutionary Zoology and Genetics, Far East Division Russian Academy of Sciences, Vladivostok 690022, Russia; Jang Geun Oh [ojg6532@korea.kr], Research Center of Environment, Jeju 690-170, Korea; Damdingiin Bayarkhagva [dambayar@yahoo.com], Department of Molecular Biology, National University of Mongolia, Ulaanbaatar 210646, Mongolia; Byeng Gug Yang [yangbg@korea.kr], National Institute of Environmental Research, Incheon 404-708, Korea; Na Hyun Ahn [multi01@naver.com], Department of Biology, Chungbuk National University, Cheongju 361-763, Korea; Dava Bazarsad [davaa69@yahoo.com], Department of Molecular Biology, National University of Mongolia, Ulaanbaatar 210646, Mongolia.

\section{Обнаружение двух симпатрических филогрупп азиатского барсука Meles leucurus (Carnivora: Mammalia) по результатам анализа гена цитохрома $b$ митохондриальной ДНК}

\author{
Хан Сун Ко, А. Крюков, Зан Гён О, Дамдингин Баярхягва, \\ Бйян Гуг Ян, На Хюн Ан, Дава Базарсад
}

РЕЗЮМЕ. Полученные 20 полных последовательностей гена цитохрома $b$ (1140 пн) Meles leucurus из Кореи (Корейского полуострова и острова Чеджу), Дальнего Востока России и Монголии были сопоставлены с извлеченными из Генбанка полными и частичными (629 пн) сиквенсами с целью оценки генетической дифференциации азиатского барсука M. leucurus на протяжении его ареала в Корее, Сибири, на Дальнем Востоке России, в Монголии и Китае. Обнаружено наличие двух симпатрических филогрупп: основная соответствует популяциям Урала, Сибири, Монголии, Китая и материковой Кореи, тогда как меньшая - популяциям Китая, российского Дальнего Востока, материковой Кореи и острова Чеджу. Этот результат свидетельствует о монотипичности M. leucurus по данному маркеру и не поддерживает современную классификацию вида, трактующего его как политипический. Для подтверждения этого вывода необходимы дальнейшие генетические исследо- 
вания с помощью других маркеров. Предполагается, что популяции M. leucurus Китая и Дальнего Востока России находились в контакте с популяциями Корейского полуострова и Чеджу на протяжении последнего ледникового периода, хотя на Чеджу и Дальнем Востоке и сейчас встречаются носители одного и того же гаплотипа. Кроме того, мы полагаем, что уровень дивергенции между островным видом $M$. anakuma из Японии и материковым $M$. leucurus не очень велик - наши генетические данные не подтверждают современной классификации, рассматривающей M. leucurus как отдельный вид, и необходим дальнейший таксономический анализ для выяснения видового статуса M. anakuma.

КЛЮЧЕВЫЕ СЛОВА: геносистематика, филогеография, цитохром b, Meles leucurus, Азия.

\section{Introduction}

The Asian badger (Meles leucurus Hodgson, 1847) is distributed in Russia (from Volga River through Siberia), Kazakhstan, China, and Korea (Wozencraft, 2005), and from Korea one subspecies (M. l. melanogenys) was reported (Allen \& Andrew, 1913), whereas from China six subspecies (M. l. leucurus, M. l. amurensis, M. l. leptorhynchus, $M$. l. raddei, M. l. tianschanensis, and M. l. blanfordi) were listed (Zhang et al., 1997). However, five subspecies (M. l. leucurus, $M$. l. amurensis, M. l. arenarius, M. l. sibiricus, and M. $l$. tianschanensis) were recognized among 18 nominal subspecies (Wozencraft, 2005), and from a morphometric analysis $M$. leucurus was shown to contain two subspecies (M. l. leucurus and M. l. amurensis) (Abramov \& Puzachenko, 2006), indicating that subspecies classification of M. leucurus is still in dispute.

Nuclear genes with a slower rate of evolution are useful for phylogeny construction at a higher level, whereas mitochondrial DNA (mtDNA) is suitable for classification at the species level and the examination of population structures within a species (Sunnucks, 2000). Evolutionary relationships among weasel-like carnivorans (Musteloidea) were inferred, based on a concatenated (8492 bp) nuclear-mitochondrial DNA data set (Sato et al., 2012), and phylogeographic structure in the badger (M. meles, M. leucurus, and $M$. anakuma in genus Meles) across Eurasia was investigated from cytochrome $b$ sequences (Kurose et al., 2001), control region sequences (Marmi et al., 2006), and $S R Y$ gene and control region sequences (Tashima et al., 2011).

For examination of population structures within $M$. leucurus, Marmi et al. (2006) used nine partial control region sequences (512 bp) from Asia (Siberian Russia, Kazakhstan, and Mongolia), and Tashima et al. (2011) utilized two $S R Y$ sequences and seven partial control region sequences (539-545 bp) from Primorye, Transbaikalia, Chelyabinsk, and Kirov in Russia. On the other hand, one cytochrome $b$ haplotype of M. leucurus from Transbaikalia (eastern Siberia) was used for the comparison with other two Meles species (Kurose et $a l ., 2001)$, indicating that cytochrome $b$ sequence analysis of $M$. leucurus, with more numerous specimens from the Korean Peninsula and other distribution regions, has not been performed yet.
Peripheral populations are often genetically and morphologically divergent from central populations, and natural barriers to dispersal, which limit species distribution, include mountain range and rivers (Goldberg \& Land, 2007). Moreover, island populations should diverge over time (morphologically and genetically) from the respective mainland species populations (Johnson et al., 2000). Northern boundary of the Korean Peninsula is formed naturally by Yalu River, Baitou Mountain (the main peak of the Changbai Mountains in northeastern China, $2744 \mathrm{~m}$ above sea level), and Tumen River, whereas Jeju Island, located near the southern coast of mainland Korea, was formed by a series of volcanic activities at the end of the Neogene (Park, 1985).

In addition, the badgers of genus Meles entered into the Japanese islands through mainland Korea (Tashima et al., 2011). Thus, it appeared that cytochrome $b$ sequencing analysis with $M$. leucurus specimens from the Korean Peninsula is necessary to perform in order to reexamine genetic divergence among $M$. leucurus populations from Asia and genetic distinctness of the three species of genus Meles as well.

In this paper, we obtained 20 complete cytochrome $b$ sequences (1140 bp) from the Korean Peninsula (mainland Korea and Jeju Island), Russian Far East, and Mongolia, and these sequences were compared with the corresponding four complete haplotypes from Siberian Russia and Mongolia, obtained from GenBank, in order to reexamine genetic divergence among M. leucurus from Korea, Siberian and Far-eastern Russia, and Mongolia. In addition, three partial (629 bp) cytochrome $b$ sequences from China, obtained from GenBank, were also used for this study to examine Chinese specimens as well.

\section{Material and methods}

For mtDNA cytochrome $b$ sequence analyses of $M$. meles, we collected 20 specimens from eight locations in four regions (mainland Korea, Jeju Island, Far-eastern Russia, and Mongolia), as given in Table 1. The eight collection sites (1, Mt. Seolak; 2, Mt. Sobaek; 3, Mt. Weolak; 4, Mt. Jiri; 5, Seoguipo; 6, Primorye, Anuchinski District; 7, Primorye, Krasnoarmeysky District; and 8, Mongolia, Dundgovi Province) are shown in Figure 1. Small pieces of muscle tissues were collected and preserved in a deep freezer. 
Table 1. List of the specimens analyzed for the complete cytochrome $b$ gene sequences (1140 bp). Locality numbers correspond to those of Fig. 1. Haplotype codes correspond to those of Figs. 2 and 3.

\begin{tabular}{|c|c|c|c|c|c|}
\hline Specimens No. & Haplotype code & Sampling locality & $\begin{array}{l}\text { Locality } \\
\text { number }\end{array}$ & $\begin{array}{c}\text { Accession } \\
\text { No. }\end{array}$ & Source \\
\hline 2493 & Sa01Korea & \multirow{2}{*}{$\begin{array}{l}\text { Korea, Mt. Seolak, } \\
38^{\circ} 06^{\prime} \mathrm{N}, 128^{\circ} 28^{\prime} \mathrm{E}\end{array}$} & \multirow{2}{*}{1} & KF891481 & \multirow{2}{*}{ This study } \\
\hline 2494 & Sa02Korea & & & KF891482 & \\
\hline 2555 & Sb01Korea & $\begin{array}{l}\text { Korea, Mt. Sobaek, } \\
36^{\circ} 57^{\prime} \mathrm{N}, 128^{\circ} 29^{\prime} \mathrm{E}\end{array}$ & 2 & KF944283 & This study \\
\hline 2495,2496 & Wa02Korea & \multirow{2}{*}{$\begin{array}{l}\text { Korea, Mt. Weolak, } \\
36^{\circ} 54^{\prime} \mathrm{N}, 128^{\circ} 05^{\prime} \mathrm{E}\end{array}$} & \multirow{2}{*}{3} & KF891478 & \multirow{2}{*}{ This study } \\
\hline 2497 & Wa01Korea & & & KF891483 & \\
\hline 2523 & Jr01Korea & \multirow{2}{*}{$\begin{array}{l}\text { Korea, Mt. Jiri, } 35^{\circ} 18^{\prime} \mathrm{N}, \\
127^{\circ} 34^{\prime} \mathrm{E}\end{array}$} & \multirow{2}{*}{4} & KF891479 & \multirow{2}{*}{ This study } \\
\hline 2524 & Jr02Korea & & & KF891480 & \\
\hline $\begin{array}{l}2499,2500,2504, \\
2505\end{array}$ & Sg01Jeju & \multirow{3}{*}{$\begin{array}{l}\text { Korea, Jeju Island, } \\
\text { Seoguipo, } 33^{\circ} 30^{\prime} \mathrm{N}, \\
126^{\circ} 31^{\prime} \mathrm{E}\end{array}$} & \multirow{3}{*}{5} & KF891477 & \multirow{3}{*}{ This study } \\
\hline 2501 & Sg02Jeju & & & KF891475 & \\
\hline $2502,2503,2506$ & Sg03Jeju & & & KF891476 & \\
\hline 2605 & Ac01FERussia & $\begin{array}{l}\text { Russia, Primorye, } \\
\text { Anuchinski District, } \\
43^{\circ} 59^{\prime} \mathrm{N}, 133^{\circ} 07^{\prime} \mathrm{E}\end{array}$ & 6 & KF944285 & This study \\
\hline 2602 & Kn01FERussia & $\begin{array}{l}\text { Russia, Primorye, } \\
\text { Krasnoarmeysky District, } \\
45^{\circ} 45^{\prime} \mathrm{N}, 135^{\circ} 30^{\prime} \mathrm{E}\end{array}$ & 7 & KF944284 & This study \\
\hline 2582 & Dd01Mongolia & \multirow{2}{*}{$\begin{array}{l}\text { Mongolia, Dundgovi } \\
\text { Province, } 45^{\circ} 54^{\prime} \mathrm{N} \text {, } \\
108^{\circ} 53^{\prime} \mathrm{E}\end{array}$} & \multirow{2}{*}{8} & KF944286 & \multirow{2}{*}{ This study } \\
\hline \multirow[t]{8}{*}{2583} & Dd02Mongolia & & & KF944287 & \\
\hline & AB049807ESiberia & $\begin{array}{l}\text { Russia, Transbaikalia, } \\
54^{\circ} 00^{\prime} \mathrm{N}, 118^{\circ} 00^{\prime} \mathrm{E}\end{array}$ & & AB049807 & $\begin{array}{l}\text { Kurose et al., } \\
2001\end{array}$ \\
\hline & HQ711949WSiberia & $\begin{array}{l}\text { Russia, Urals, Orenburg } \\
\text { Province, } 51^{\circ} 47^{\prime} \mathrm{N}, \\
55^{\circ} 06^{\prime} \mathrm{E}\end{array}$ & & HQ711949 & $\begin{array}{l}\text { Del Cerro et al., } \\
\text { unpublished }\end{array}$ \\
\hline & HQ711951WSiberia & $\begin{array}{l}\text { Russia, Urals, } \\
\text { Chelyabinsk Province, } \\
55^{\circ} 09^{\prime} \mathrm{N}, 61^{\circ} 22^{\prime} \mathrm{E}\end{array}$ & & HQ711951 & $\begin{array}{l}\text { Del Cerro et al., } \\
\text { unpublished }\end{array}$ \\
\hline & HQ711950Mongolia & Mongolia & & HQ711950 & $\begin{array}{l}\text { Del Cerro et al., } \\
\text { unpublished }\end{array}$ \\
\hline & EF632294China & \multirow{3}{*}{ China } & & EF632294* & \multirow{3}{*}{$\begin{array}{l}\text { Kazehanof, } \\
\text { unpublished }\end{array}$} \\
\hline & EF632295China & & & EF632295* & \\
\hline & EF632296China & & & EF632296* & \\
\hline
\end{tabular}

* partial sequences (629 bp).

Total cellular DNA was extracted using a genomic DNA extraction kit (Intron Co., Daejeon, Korea). The cytochrome $b$ gene was PCR-amplified, using primers L14724 and H15915, designed by Irwin et al. (1991), and PCR thermal cycle was as follows: $94^{\circ} \mathrm{C}$ for $5 \mathrm{~min}$; $94^{\circ} \mathrm{C}$ for $1 \mathrm{~min}, 58^{\circ} \mathrm{C}$ for $1 \mathrm{~min}$, and $72^{\circ} \mathrm{C}$ for $1 \mathrm{~min}(30$ cycles); and $72^{\circ} \mathrm{C}$ for $5 \mathrm{~min}$. The amplified products were purified using a DNA PrepMate kit with a silicabased matrix at Bioneer Co. (Cheongju, Korea) for the removal of primers and the unincorporated nucleotides. Sequencing of the purified PCR products was carried out using an automated DNA Sequencer (Perkin Elmer 377) at Macrogen Co. (Seoul, Korea).

The 20 complete cytochrome $b$ sequences (1140 bp) from mainland Korea, Jeju Island, Far-eastern Russia, and Mongolia were compared to the four complete haplotypes of M. leucurus from the Urals, Siberia and Mongolia, obtained from GenBank, as listed in Table 1. In addition, partial (629 bp: site nos. 206-834) cytochrome $b$ sequences were obtained from the 24 complete sequences (20 sequences from this study and four sequences from GenBank), and these partial sequences were analyzed together with three partial haplotypes (EF632293-EF632295) from China, obtained from GenBank, as given in Table 1, because complete sequences from China were not available from GenBank. One partial cytochrome $b$ haplotype from China (EF632293) was not used in this study, because this haplotype was identical to the EF632296 in their sequences.

Sequence alignments, model selections, and tree constructions with 1000 bootstrapped replications were conducted using MEGA5 (Tamura et al., 2011): the 


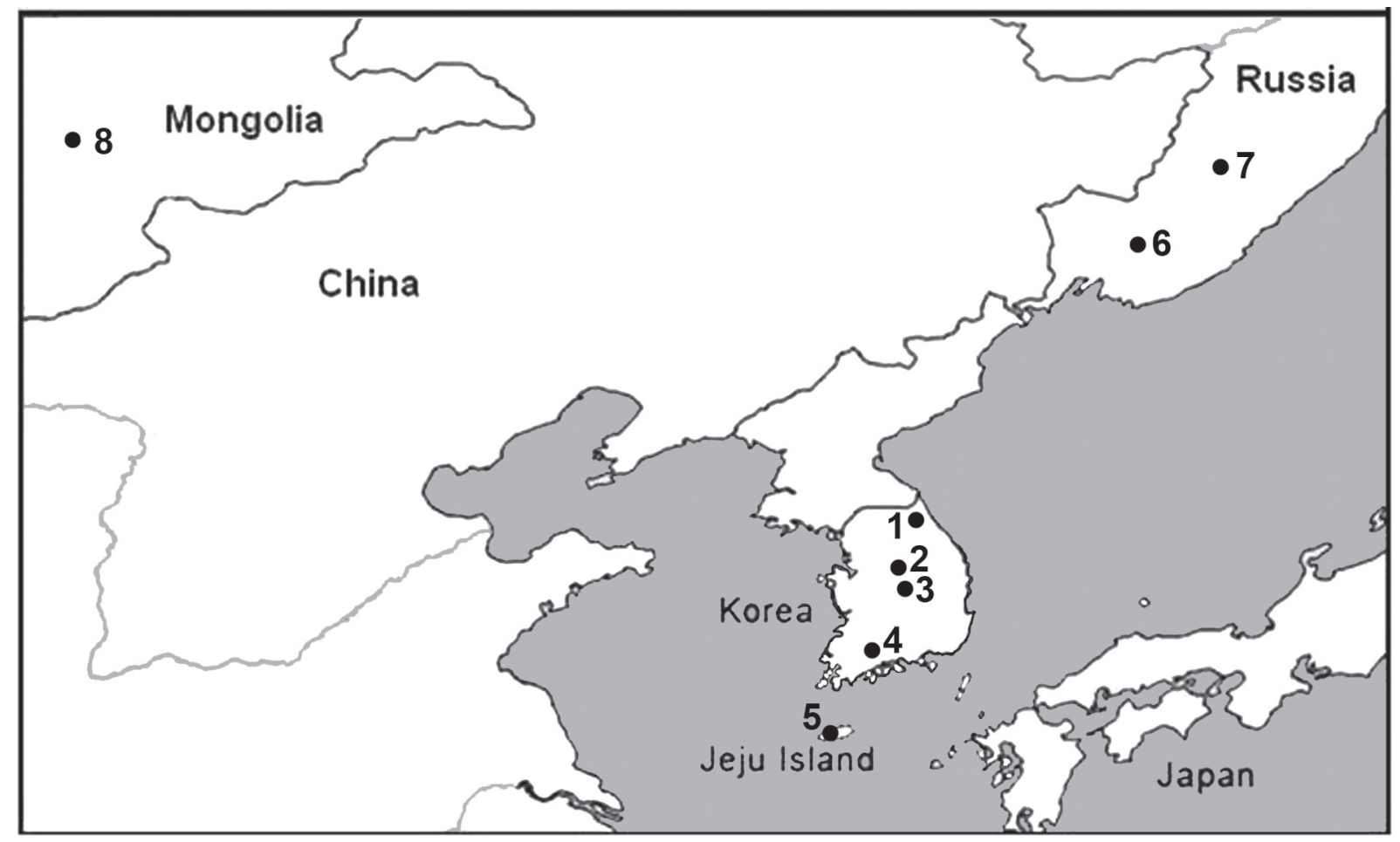

Figure 1. Collection sites for 20 specimens of Meles leucurus from eight locations in the Korean Peninsula, Far-eastern Russia, and Mongolia, used in this study. Four sites for eight specimens from mainland Korea are Mt. Seolak (1); Mt. Sobaek (2); Mt. Weolak (3); and Mt. Jiri (4), and one location for eight specimens from Jeju Island is Seoguipo (5); two sites from Fareastern Russia are Anuchinski District (6) and Krasnoarmeysky District (7), and one site from Mongolia is Dundgovi Province (8). Specimen number from each location is listed in Table 1.

Jukes-Cantor (JC) model, which showed the lowest Bayesian information criterion score, was chosen as the best model for our data by the program, and maximum likelihood tree was constructed using the JC model. Meles anakuma (AB049791 and AB049803) and $M$. meles (AB049808 and AB049809) were used for the comparison, and Arctonyx collaris (AB049810) and Mustela sibirica (JQ739197) were used as outgroups.

\section{Results}

From the 20 complete cytochrome $b$ sequences ( 1140 bp) of M. leucurus from Asia, 14 haplotypes (seven from mainland Korea, three from Jeju Island, two from Far-eastern Russia, and two from Mongolia) were identified, as given in Table 1 (GenBank accession nos. of the 14 haplotypes are KF891475-KF891483 and KF944283-KF944287). Within the 18 cytochrome $b$ haplotypes of M. leucurus (14 haplotypes from this study and four haplotypes from GenBank), 34 sites $(2.98 \%)$ were variable and 21 sites $(1.84 \%)$ were parsimony informative.

A maximum likelihood tree with the 18 complete cytochrome $b$ haplotypes of M. leucurus is shown in Figure 2, and two subgroups were recognized (Gps 1 and 2). The Gp 1 (nine haplotypes from Siberian Russia, Mongolia, and mainland Korea) was divergent from the Gp 2 (nine haplotypes from Far-eastern Russia, mainland Korea, and Jeju Island), with average JC distance of $1.46 \%$ and ten fixed site differences (at site nos. 102, 351, 528, 568, 883, 960, 1011, 1029, 1068, and 1113, nucleotide bases in the haplotypes of the Gp 1 were A, C, T, G, A, G, A, A, C, and C, whereas those in the haplotypes of the Gp 2 were $G, T, A, T, G, A, G$, $\mathrm{G}, \mathrm{T}$, and T): average JC distances within the Gp 1 and the Gp 2 were $0.48 \%$ and $0.27 \%$, respectively. The average JC distance between the three haplotypes from mainland Korea (Gp 1, in part) and the six haplotypes from Siberian Russia and Mongolia (Gp 1, the rest) was $0.63 \%$, whereas average JC distance between the three haplotypes from Jeju (Gp 2, in part) and other six haplotypes from mainland Korea and Far-eastern Russia ( $\mathrm{Gp} 2$, the rest) was $0.32 \%$.

In addition, a maximum likelihood tree with the 21 partial (629 bp) cytochrome $b$ haplotypes of M. leucurus (14 haplotypes from this study and seven haplotypes from GenBank) is shown in Figure 3, and two subgroups were also revealed (Gps 1 and 2). The Gp 1 (11 haplotypes from Siberian Russia, Mongolia, China, and mainland Korea) was divergent from the Gp 2 (ten haplotypes from Far-eastern Russia, China, mainland Korea, and Jeju Island) with average JC distance of $0.93 \%$ and three fixed sits differences (site nos. 351, 528, and 568). The average JC distances within the Gp 1 and the Gp 2 were $0.32 \%$ and $0.21 \%$, respectively. 


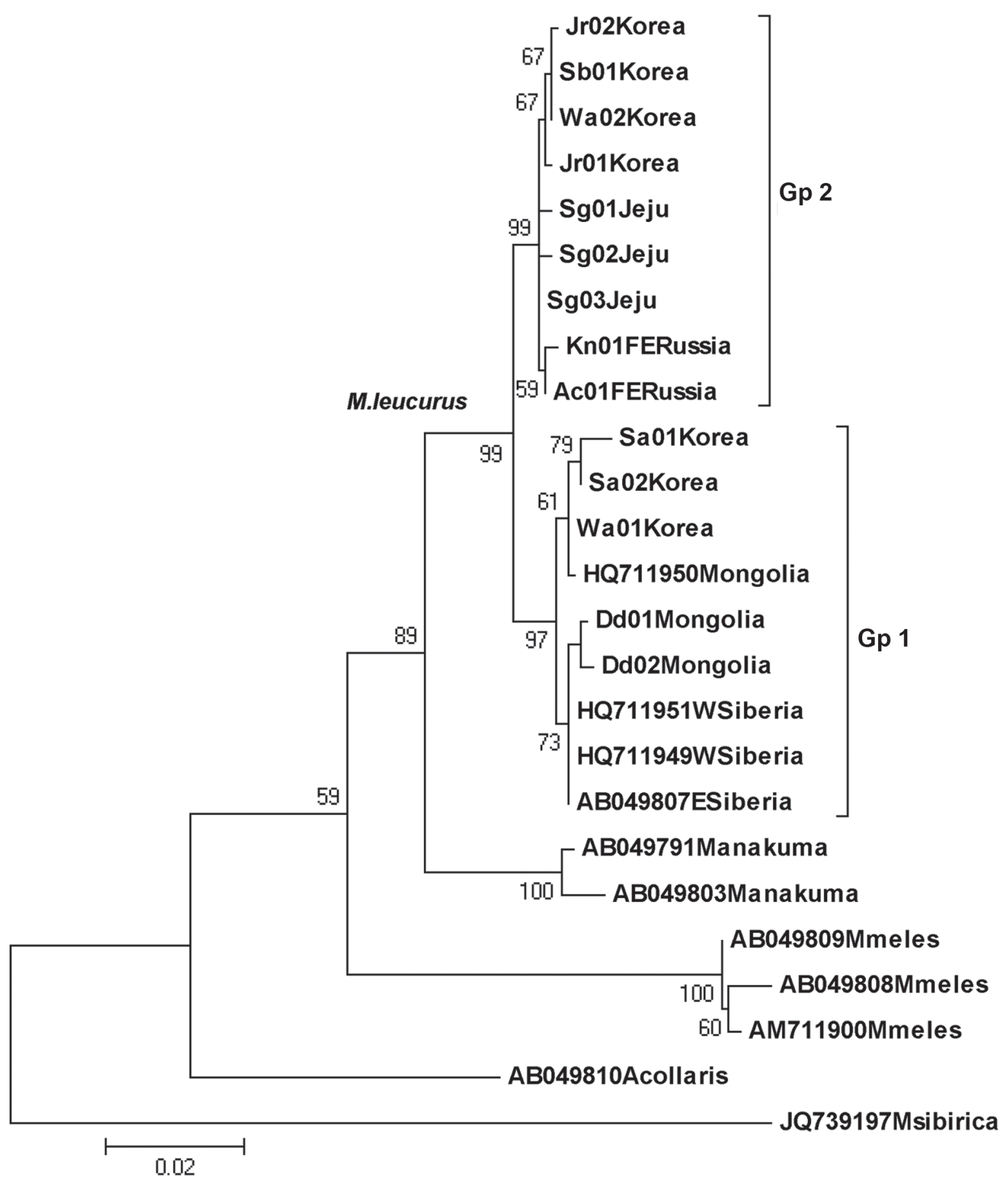

Figure 2. Maximum likelihood tree with 18 complete (1140 bp) cytochrome b haplotypes of Meles leucurus. The 14 haplotypes from the Korean Peninsula, Far-eastern Russia, and Mongolia were obtained from this study, as given in Table 1, and location name follows the accession number in each of the four haplotypes, obtained from GenBank, as listed in Table 1. The bootstrap values $>50 \%$ are reported at the internodes. Meles anakuma (AB049791 and AB049803) and M. meles (AB049808 and AB049809) were used for the comparison, and Arctonyx collaris (AB049810) and Mustela sibirica (JQ739197) were used as outgroups. 


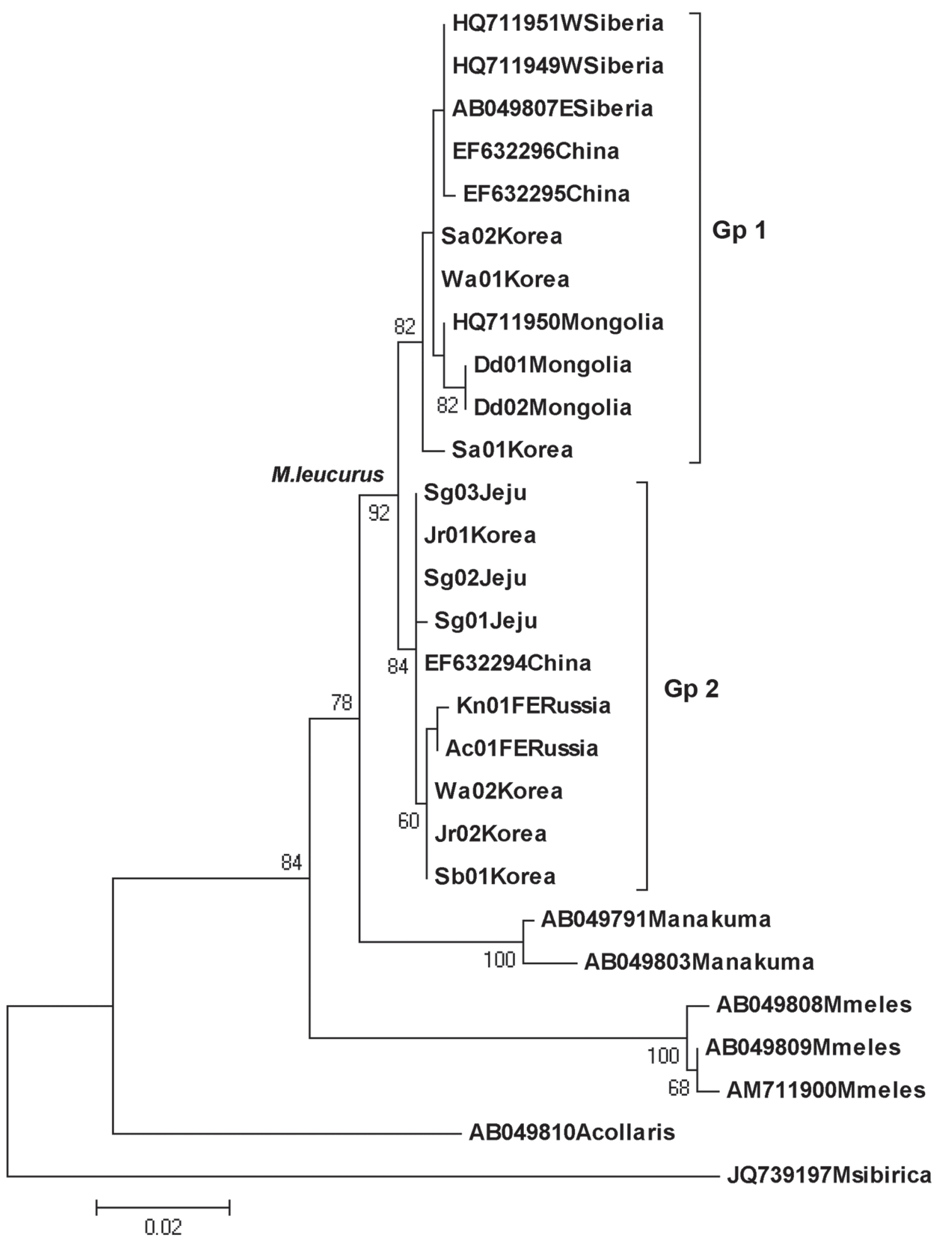

Figure 3. Maximum likelihood tree with 21 partial (629 bp) cytochrome $b$ haplotypes of Meles leucurus. The 14 haplotypes from the Korean Peninsula, Far-eastern Russia, and Mongolia were obtained from this study, as given in Table 1, and location name follows the accession number in each of the seven haplotypes, obtained from GenBank, as listed in Table 1. The bootstrap values $>50 \%$ are reported at the internodes. 
Additionally, as shown in Figure 2, M. leucurus (Gps 1 and 2) was divergent from $M$. anakuma, with average JC distance of $4.31 \%$ (range, 3.78-5.08\%), but these two species were grouped together, with a 0.85 bootstrap value. On the other hand, M. leucurus and $M$. anakuma were divergent from $M$. meles, with average JC distance of $8.48 \%$ (range, 7.95-9.03\%), and these three species were clustered together, with a 0.59 bootstrap value.

\section{Discussion}

Avise \& Walker (1999) reported that about 140 of 252 species of vertebrates were subdivided clearly into two or more highly distinctive matrilineal phylogroups with at least $0.6 \%$ sequence diversity in mtDNA, and that the vast majority of these phylogroups were localized geographically. Bradley \& Baker (2001) concluded that a genetic distance of less than $2 \%$ based on cytochrome $b$ gene was typical of populational and intraspecific variation. In this complete and partial cytochrome $b$ sequencing study (Figs. 2 and 3), we detected that $M$. leucurus is composed of two subgroups (Gp 1, a major subgroup with wide distribution range from Siberian Russia, Mongolia, China, and mainland Korea; and Gp 2, a minor subgroup with narrow distribution range from Far-eastern Russia, China, mainland Korea, and Jeju Island), with average JC distances of $1.46 \%$ and $0.93 \%$ in the complete (1140 bp) and partial (629 bp) cytochrome $b$ sequences, respectively. Thus, we found that $M$. leucurus is composed of two matrilineal phylogroups, which are sympatric in mainland Korea and China.

In general, a subspecies is an aggregate of phenetically similar populations of a species, differing taxonomically from other populations of that species (Mayr \& Ashlock, 1991), although it was advocated that a classification should reflect all available characters distributed as widely and evenly as possible over the organisms studied (Huelsenbeck et al., 1996). In subspecies classification of $M$. leucurus, two subspecies (M. l. leucurus from Siberia and M. l. amurensis from China and Far-eastern Asia) were recognized from a morphometric analysis (Abramov \& Puzachenko, 2006). However, from the previous studies based on $S R Y$ and partial control region sequences from Asia, except Korea and China (Marmi et al., 2006; Tashima et al., 2011), population subdivision within $M$. leucurus was not shown.

From this study based on complete and partial cytochrome $b$ sequences, including ten Korean haplotypes (Figs. 2 and 3), M. leucurus from Siberian Russia, Mongolia, China, and mainland Korea formed the major phylogroup (Gp 1), and based on complete cytochrome $b$ sequences (Fig. 2) average JC distance between the three haplotypes from mainland Korea (Gp 1, in part) and the six haplotypes from Siberian Russia and Mongolia (Gp 1, the rest) was $0.63 \%$, indicating that $M$. l. leucurus from Siberia and M. l. amurensis from other regions, classified by Abramov \& Puzachenko (2006), are not different in the cytochrome $b$ sequences. Thus, we concluded that $M$. leucurus is a monotypic species in the cytochrome $b$ sequences, and that our sequencing results also do not support current subspecies classification of $M$. leucurus, recognizing it as a polytypic species (Wozencraft, 2005), although further genetic analyses with other markers are needed to confirm our present findings.

The Yellow Sea separating Korea and central and part of northeastern China was land during the last glacial period (Chung, 2007), and large areas of continental shelf was dry land, allowing easy exchange of plant and animal species by land bridge connections to what are now isolated islands at the end of the last glacial period (Lomolino et al., 2010). In this complete and partial cytochrome $b$ sequence study (Figs. 2 and 3), M. leucurus from mainland Korea (Gp 1, in part) was not divergent from M. leucurus in Siberian Russia, China, and Mongolia (Gp 1, the rest), and Jeju $M$. leucurus (Gp 2, in part) was not distinct from mainland Korean, Chinese, and Far-eastern Russian M. leucurus (Gp 2, the rest). Thus, we considered that M. leucurus from China and Far-eastern Russia is in contact with that from mainland Korea and insular Jeju during the last glacial period although in Jeju and Far-eastern Russia the specimens belonging to one of the two phylogroups are living at present.

Additionally, three species of genus Meles (M. meles from Europe, M. leucurus from continental Asia, and $M$. anakuma from Japan) were classified based on morphometric characters (Abramov, 2002; Abramov \& Puzachenko, 2006), mtDNA cytochrome $b$ sequences (Kurose et al., 2001), partial control region sequences (Marmi et al., 2006), and nuclear SRY gene and mitochondrial partial control region sequences (Tashima et al., 2011). In this study with the 18 complete cytochrome $b$ haplotypes, including ten Korean haplotypes (Fig. 2), we found that both M. anakuma and M. leucurus were divergent from $M$. meles, with average JC distance of $8.48 \%$ (range, 7.95-9.03\%), and these three species were clustered together, with lower bootstrap value of 0.59 , indicating that this results support the species status of $M$. meles.

On the other hand, in this study (Fig. 2) M. anakuma was found to be divergent from M. leucurus, with average JC distance of $4.31 \%$ (range, 3.78-5.08\%), but these two species were grouped together, with higher bootstrap value of 0.85 . In addition, in a previous study with the control region sequences $M$. anakuma from Japan and M. leucurus from continental Asia formed a larger cluster, with bootstrap value of 0.99 (Tashima et $a l ., 2011)$. In a previous cytochrome $b$ sequence analysis, $M$. anakuma and $M$. leucurus were clustered together, with lower bootstrap value of 0.68 (Kurose et al., 2001), but they used only one M. leucurus haplotype to compare with $17 \mathrm{M}$. anakuma haplotypes.

Moreover, Bradley \& Baker (2001) concluded that genetic distances between $2 \%$ and $11 \%$ had a high probability of being indicative of conspecific popula- 
tions or valid species. Thus, we considered that the degree of genetic divergence between insular $M$. anakuma from Japan and continental M. leucurus from mainland Asia is not so great that our sequencing results do not support current species classification of genus Meles, recognizing $M$. leucurus as a distinct species. We proposed further systematic analyses to clarify the specific status of $M$. anakuma.

\section{References}

Abramov A.V. 2002. Variation of the baculum structure of the Palearctic badger (Carnivora, Mustelidae, Meles) // Russian Journal of Theriology. Vol.1. P.57-60.

Abramov A.V., Puzachenko A.Y. 2006. Geographical variability of skull and taxonomy of Eurasian badgers (Mustelidae, Meles) // Zoologicheskii Zhurnal. Vol.85. P.641655.

Allen J.A., Andrew R.C. 1913. Mammals collected in Korea // Bulletin of the American Museum of Natural History. Vol.32. P.427-436.

Avise J.C., Walker D. 1999. Species realities and numbers in sexual vertebrates: perspectives from an asexual transmitted genome // Proceedings of the National Academy of Sciences of the United States of America. Vol.96. P.992-995.

Bradley R.D., Baker R.J. 2001. A test of the genetic species concept: cytochrome $b$ sequences and mammals // Journal of Mammalogy. Vol.82. P.960-973.

Chung C.H. 2007. Vegetation response to climate change on Jeju Island, South Korea, during the last glaciations based on pollen record // Geosciences Journal. Vol.11. P.147-155.

Goldberg E.E., Land L. 2007. Species and dispersal barriers // American Naturalist. Vol.170. P.297-304.

Huelsenbeck J.P., Bull J.J., Cunningham C.W. 1996. Combining data in phylogenetic analysis // Trends in Ecology \& Evolution. Vol.11. P.152-158.

Irwin D.M., Kocher T.D., Wilson A.C. 1991. Evolution of the cytochrome $b$ gene of mammals // Journal of Molecular Evolution. Vol.32. P.128-144.

Johnson K.P., Adler F.R., Cherry J.L. 2000. Genetic and phylogenetic consequences of island biogeography // Evolution. Vol.54. P.387-396.
Kurose N., Kaneko Y., Abramov A.V., Siriaroonrat B., Masuda R. 2001. Low genetic diversity in Japanese populations of the Eurasian badger Meles meles (Mustelidae, Carnivora) revealed by mitochondrial cytochrome $b$ gene sequences // Zoological Science. Vol.18. P.1145-1151.

Lomolino M.V., Riddle B.R., Whittaker R.J., Brown J.H. 2010. Biogeography. Fourth edition. Sunderland, MA: Sinauer Associates. 878 p.

Marmi J., Lopez-Giraldez F., Macdonald D.W., Calafell F., Zholnerovskaya E., Domingo-Roura X. 2006. Mitochondrial DNA reveals a strong phylogeographic structure in the badger across Eurasia // Molecular Ecology. Vol.15. P.1007-1020.

Mayr E., Ashlock P.D. 1991. Principles of Systematic Zoology. New York: McGraw-Hill Inc. 475 p.

Park D.W. 1985. [Geology of coasts and mountains in ChejuDo] // [Cheju-Do Study]. Vol.2. P.321-322 [in Korean].

Sato J.J., Wolsan M., Prevosti F.J., D’Elia G.D., Begg C., Begg K., Hosoda T., Campbell K.L., Suzuki H. 2012. Evolutionary and biogeographic history of weasel-like carnivores (Musteloidea) // Molecular Phylogenetic and Evolution. Vol.63. P.745-757.

Sunnucks P. 2000. Efficient genetic markers for population biology // Trends in Ecology \& Evolution. Vol.15. P.199203.

Tamura K., Peterson D., Peterson N., Stecher G., Nei M., Kumar S. 2011. MEGA5: molecular evolutionary genetic analysis using maximum likelihood, evolutionary distance, and maximum parsimony methods // Molecular Biology and Evolution. Vol.28. P.2731-2739.

Tashima S., Kaneko Y., Anezaki T., Baba M., Yachimori S., Abramov A.V., Saveljev A.P., Masuda R. 2011. Phylogeographic sympatry and isolation of the Eurasian badgers (Meles, Mustelidae, Carnivora): implications for an alternative analysis using maternally as well paternally inherited genes // Zoological Science. Vol.28. P.293303.

Wozencraft W.C. 2005. Order Carnivora // Wilson D.E. \& Reeder D.M. (eds.). Mammal Species of the World: a Taxonomic and Geographic Reference. Third edition. Baltimore: Jones Hopkins University Press. P.532-628.

Zhang Y., Sangke J., Guoqiang J., Shibau L., Zhongyao Y., Genggui W., Manli Z. 1997. Distribution of Mammalian Species in China. Beijing: China Forestry Publishing House. 280 p. 